\title{
Corporate Governance, Firm Risk, And Corporate Social Responsibility: Evidence From Korean Firms
}

\author{
Sewon Lee, Ajou University, South Korea \\ Young Kon Kim, Ajou University, South Korea \\ Kyungho Kim, Ajou University, South Korea
}

\begin{abstract}
Given that the prior studies on the relationship between corporate governance structures and firm performance are silent on firms' social responsible roles, this study introduces an integrated model by combining corporate social responsibility (CSR) and corporate governance structures. This model is used to investigate how CSR moderates the relationship between corporate governance and firm risk in a sample of 640 firm-by-year cases for 215 firms listed on the Korea Exchange between 2005 and 2010. The results show that foreign ownership and board size have a significant and negative relationship with firm risk, whereas management ownership and outside director ratio have no significant effect on firm risk. The results demonstrate that CSR partially moderates the relationship between governance structures (especially management ownership and board size) and firm risk. These findings suggest that Korean firms with concentrated ownership structures can leverage CSR activities as invisible assets to achieve more efficient governance structure model.
\end{abstract}

Keywords: Corporate Governance; Corporate Social Responsibility; Firm Risk; Stakeholder Theory

\section{INTRODUCTION}

1 n Korean business context, agency problems caused by conflicting interests between owner-manager and outside shareholders are a common issue, especially given that large publicly-owned Korean firms have concentrated ownership structure (Park \& Noh, 2008). Although outside shareholders (e.g. minority shareholders) pursue capital gains through increased firm value, owner-managers have incentives to exert their influence to secure private benefits. Thus, it is important to have transparency in governance mechanisms to protect minority shareholders from the managers' moral hazard, as well as reduce firm risk (Lee et al., 2005).

How firms perform their roles and functions has been a fundamental issue on corporate governance studies (Berle \& Means, 1932; Claessens et al., 2000). The existing empirical studies of governance structures have examined how individuals who have contractual relationships with firms influence firms' performance and how corporate governance mechanisms can be improved by maximizing shareholder value (Agrawal \& Mandelker, 1987; Fama \& Jensen, 1983; Jensen \& Meckling, 1976; McConnell \& Servaes, 1990; Morck et al., 1988; Shleifer \& Vishny, 1986). These studies have focused on explanations of how firms carry out the roles to protect the interests of shareholders.

As noted by Freeman and Reed (1983), however, a corporation is responsible to a variety of stakeholders, including shareholders. In recent decades, numerous scholars have contended that diverse stakeholders increasingly affect firms' performance, and even their survival (Clarkson, 1995; Cornell \& Shapiro, 1987; Freeman, 1984). The stakeholder perspective extends the concept of stakeholders and it emphasizes the connection between a wide range of stakeholders and firm performance (Cornell \& Shapiro, 1987).

Considering firms' social responsibilities on a wide range of stakeholders, existing governance models are insufficient to explain the firm behaviors in social systems. The relationship between corporate social responsibility (CSR) and firm performance has drawn attention in the field of strategic management (Aupperle et al., 1985; Cochran \& Wood, 1984; Hillman \& Keim, 2001; McWilliams \& Siegel, 2000; Preston \& O’Bannon, 1997; 
Waddock \& Graves, 1997). We acknowledge that if firms are engaged in CSR, they can build social capital from the committed stakeholder relationships. Indeed, firms can develop intangible assets such as corporate reputation and trust by investing in better stakeholder relations (Hillman \& Keim, 2001; Jones, 1995; Roberts \& Dowling, 2002). Such social assets from CSR can affect motivations of members and decision-making procedures in corporate governance, thereby reducing firm risk. Accordingly, this study introduces an integrated model in which CSR activities can moderate the relationship between governance structure and firm risk.

In the following section, we review existing literature relating to corporate governance and CSR and then formulate hypotheses. Next, we conduct empirical tests by employing 640 firm-by-year cases from 215 Korean companies between 2005 and 2010. Finally, we provide the results, as well as concluding remarks.

\section{LITERATURE REVIEW}

\section{Corporate Governance and Firm Performance}

Modern corporations formulate a separation of ownership and control, causing agency problems (Berle \& Means, 1932). Jensen and Meckling (1976) clarify agency problems by arguing that agency costs consist of (1) monitoring expenditures by the principals, (2) bonding expenditures by the agents, and (3) residual loss. The concept of agency problems has been applied to explain how corporate governance mechanisms are related to firm performance (Fama \& Jensen, 1983; Jensen \& Meckling, 1976; McConnell \& Servaes, 1990; Morck et al., 1988).

In real world, firms are inevitably faced with such agency problems (Jensen \& Meckling, 1976). In this situation, a board of directors has been expected to play a role as a top-level decision control device to mitigate agency problems in the corporate governance, and thereby affect firm performance (Fama \& Jensen, 1983). The monitoring mechanism of corporate board is the primary way to protect shareholders as owners of the firm (Dalton et al., 1998). Although the existing corporate governance studies on the board of directors and ownership structures have explored how these mechanisms can be improved to alleviate agency problems and maximize shareholder interests, they are not sufficient to explain the firms' behaviors in social systems in that the prior studies have been silent on corporate social responsibility.

\section{Corporate Social Responsibility and Firm Performance}

Scholars increasingly contend that firms are responsible to a wide range of stakeholders, which include not only shareholders but also employees, suppliers, governmental units, communities, and natural environment (Clarkson, 1995; Cornell \& Shapiro, 1987; Freeman, 1984; Freeman \& Reed, 1983). Freeman (1984) defines a stakeholder as "any group or individual who can affect or is affected by the achievement of the organization's objectives" (p. 46). The main concern of stakeholder theory is that firms need to care for a variety of stakeholders beyond their traditional economic behavior (Freeman et al., 2004). In addition, the stakeholder perspective links stakeholder management and performance (Clarkson, 1995).

Some researchers have investigated the relationship between CSR and firm performance (Aupperle et al., 1985; Cochran \& Wood, 1984; McWilliams \& Siegel, 2000; Preston \& O’Bannon, 1997; Ullmann, 1985; Waddock \& Graves, 1997), but they provided mixed results. For example, Preston and O'Bannon (1997) observe a positive correlation between CSR and profitability. Waddock and Graves (1997) also identify CSR is positively related with both of prior financial performance and future financial performance. However, Aupperle et al. (1985) do not find any significant relationship between CSR and performance. Notwithstanding the prior mixed results, a recent metaanalysis suggests that overall relationship between CSR and financial performance is positive (Margolis et al., 2007).

This study expands the scope of firm performance measurement by using firm risk as a proxy for financial performance. Historically, firm risk is explained as an uncertainty in profitability (Bowman, 1980). Firm risk implies incomplete information and undermines of the firm's planning and strategic activities (Baird \& Thomas, 1985; Bloom \& Milkovich, 1998). This may degrade profitability and even become a threat to firm's survival (Baird \& Thomas, 1985; Fiegenbaum \& Thomas, 1988). Furthermore, true economic performance may secure stability of the performance (Orlitzky \& Benjamin, 2001). 


\section{HYPOTHESES}

\section{Corporate Governance and Firm Risk}

As mentioned earlier, Korean companies have faced agency problems stemming from a few large shareholders (i.e., a few owner-managers) (Baek et al., 2004; Joh, 2003). Given the characteristic by concentrated ownership structure of Korean large publicly-owned firms, existing studies have examined how ownership structures are related to performance and how governance structures are effective to control agency problems. If corporate governance mechanisms are effectively designed, the firm is expected to provide transparency and effectiveness of the decisionmaking process (Cho \& Kim, 2007). The improved operation of corporate governance mechanisms may help firms to reduce firm risk.

Hypothesis 1: Corporate governance will be associated with firm risk.

\section{Management Ownership}

The management ownership of Korean companies is generally convergent with the power of senior managers (Cho \& Kim, 2007). If managers share a large fraction of equity and secure power, they could have an incentive to consume perquisites and capture the board of directors, making the company work for managements' advantages rather than for shareholders' interests. Because the powerful managers do not require the necessity of compromises and agreements from other shareholders (Adams et al., 2005), their opportunistic behaviors can easily be implemented. The power of senior managers may create agency costs, becoming an obstacle to an effective governance mechanisms (Cho \& Kim, 2007). Hence, this study postulates that management ownership is likely to increase firm risk.

Hypothesis 1a: Management ownership will be positively associated with firm risk.

\section{Foreign Ownership}

Previous studies on the relationship between outside shareholders and performance focused especially on institutional investors rather than foreign ones because the latter group has tended not to share much equity in the USA, Japan, and Germany (Park et al., 2004). However, the impact of the foreign shareholders on the Korean markets and corporations has been a significant issue, given that the Korean government opened capital markets and abolished restrictions on the foreign ownership (Choi et al., 2007; Park et al., 2004). In fact, the foreign shareholders owned over 30\% of all existing stocks in the Korean market in 2011 according to the Financial Supervisory Service (FSS). As such, this study acknowledges that the foreign investors are important outside shareholders in corporate governance mechanisms.

Foreign shareholders have played an important role in monitoring managers' moral hazards and forcing firms to establish transparent corporate governance (Oh et al., 2011; Shleifer \& Vishny, 1986). Therefore, foreign investors may enhance firms' ability to manage moral hazards, leading to better relationships with among stakeholders by reducing informational asymmetries though corporate governance mechanisms. Foreign investors monitor managers' self-interested behavior. Accordingly, this study speculates that the greater the foreign ownership, the lower the firm's risk.

Hypothesis 1b: Foreign ownership will be negatively associated with firm risk.

\section{Outside Director Ratio}

The Korean government introduced the outside director system in 1998 (i.e., right after the outbreak of the Asian financial crisis). The outside director system was one of a series of corporate restructuring measures to meet the demands of the International Monetary Fund (IMF) and shareholder activists (Choi et al., 2007). The outside director system was intended to improve the corporate governance mechanisms and enhance management transparency as well as a firm competitiveness (Cho \& Kim, 2007). 
Specifically, the outside independent directors are expected to function in the monitoring role to prevent manager's self-interested behavior at the expense of shareholders because they enhance the psychological and financial independence of the board from the management (Baysinger \& Butler, 1985; Byrd \& Hickman, 1992). Considering that senior managers in Korean companies often control the board of directors for their own advantages, board independence may be an important factor in having an effective boards of directors. Accordingly, it is assumed that the outside directors will reduce agency problems and lower firm risk.

Hypothesis 1c: Outside director ratio will be negatively associated with firm risk.

Board Size

Although the board independence has been seen as the primary driver for the firm performance, board size has attracted the attention of corporate governance researchers (Dalton et al., 1999). In particular, board size is likely to be directly related with the effectiveness of the decision-making process. Cheng (2008) contends that large board size alleviates the extremes of rash or self-serving strategic decisions in corporate governance. As a board size expands, the board tends to require more negotiations among board members: that is, the decisions of a large board reflect the coordination of the members. In this process, a large board can provide more protection from radical members in decision-making, and this may lead to more stable firm performance. Hence, this study proposes that a firm can reduce the firm risk, if the firm retains a large board size.

Hypothesis 1d: Board size will be negatively associated with firm risk.

\section{Corporate Social Responsibility and Firm Risk}

CSR can be an effective strategy for risk management of firms (Orlitzky \& Benjamin, 2001). Firms can improve their reputations by investing in social issues (Herremans et al., 1993). CSR also creates goodwill that is the positive attribution from stakeholders because CSR provides good signals to external stakeholders. Good CSR activities allow firms to create social capital that offers insurance-like protection in negative situations (Godfrey, 2005; Godfrey et al., 2009). The high quality stakeholder relationships through CSR lead to better access to social capital, enabling firms to make profitable investments and avoid sharply negative performance (Cheng et al., 2014). For example, many Korean consumers want to buy products manufactured by firms that implement 'go green' strategy.

In addition, CSR can be an effective way for firms to improve from poor performance. Well implemented, CSR strengthens trust and loyalty of the firms' stakeholders. The firms can use external knowledge and information from diverse sources and combine internal and external capabilities to improve existing strategies. Choi and Wang (2009) insist that such impacts through stakeholder relations should be more effective if the firm builds relational assets before experiencing poor performance. Accordingly, we assume that CSR can be an effective strategy for risk management and, in turn, significantly reduce firm risk.

Hypothesis 2: CSR will be negatively associated with firm risk.

\section{Moderating Role of CSR}

This study emphasizes that CSR engagement builds valuable social assets for the firm. Firms can accumulate benefits such as improved reputation, trust, and legitimacy from committed stakeholder relationships (Roberts \& Dowling, 2002; Surroca et al., 2010). The social performance coming from the stakeholder's interests can, in turn, influence the corporate governance mechanisms. This is because social capital may have an impact on the motivations of members' behaviors and the effectiveness of the corporate board. Accordingly, we assume that CSR will moderate the relationship between corporate governance and firm risk.

Hypothesis 3: The relationship between corporate governance and firm risk will be moderated by decreasing effect of CSR.

In particular, firms with better performance through CSR may be evaluated and controlled based on the environmental, social, and external perceptions (Eccles et al., 2014). This situation may create a moral impact in the 
governance structure as it suppresses opportunistic behavior of the managers (Bénabou \& Tirole, 2010). It becomes difficult for the managers to exploit equity and corporate board for their own interests as the firm establishes deeper commitments to its stakeholders over time. Thus, CSR may enhance transparency and decrease agency costs for the firm (Cheng et al., 2014).

Hypothesis 3a: The positive relationship between management ownership and firm risk will be moderated by decreasing effect of CSR.

In addition, successful CSR generally indicates long-term performance and viability (Eccles et al., 2014; Kang, 2013). If a firm is engaged in CSR, the firm may have adopted a long-term performance horizon. This may stimulate the functions of foreign shareholders to be effective because the foreign shareholders usually favor a long-term perspective. CSR can motivate foreign shareholders to devote their efforts to monitor the managers' behaviors pursuing their private benefits or short-term opportunism, as well as providing valuable information to enhance firm strategies and improve firm performance.

Hypothesis 3b: The negative relationship between foreign ownership and firm risk will be moderated by decreasing effect of CSR.

CSR may even enhance effectiveness of corporate board. The monitoring role of outside directors in corporate governance might be improved as stakeholder interaction increases. If a firm is engaged in CSR, the firm may have easier access to external environment information. The information may be useful for the board to perceive management's self-interested behavior (Eccles et al., 2014). In other words, the outside directors may serve to control, punish, and reward managers more appropriately by using social connections of stakeholders.

Hypothesis 3c: The negative relationship between the outside director ratio and firm risk will be moderated by decreasing effect of CSR.

Furthermore, CSR may improve the board's operation through social connections and the firm's improved relational assets. CSR improves the firm's external links, and this may lead the board to act in more socially desirable ways. If the board is closely connected with stakeholders, it can enhance its legitimacy by signaling external and internal constituents that the board of directors represents a stakeholder orientation (Luoma \& Goodstein, 1999). We hypothesize that CSR will moderate the relationship between effectiveness of corporate board and firm risk.

Hypothesis 3d: The negative relationship between board size and firm risk will be moderated by decreasing effect of CSR.

\section{METHOD AND ANALYSIS}

\section{Sample}

This study employs a sample of 640 firm-by-year cases for 215 firms listed on the Korea Exchange (KRX) between 2005 and 2010. We initially included target firms in lists of top 200 rankings evaluated by Korea Economic Justice Institute (KEJI) index from the Citizens' Coalition for Economic Justice (CCEJ) during the observation period. We left censored the beginning of observation in 2005 because CCEJ opened the data to the public in the same year, and we right censored the observation period in 2010 to maintain the consistency of the data because the KEJI index was modified after 2010 .

Based on the KEJI data, we merged firm-level data using DataGuide 5 to obtain financial information on firm risk, ownership variables and other control variables. We also collected announcement data for board variables from the Data Analysis, Retrieval, and Transfer (DART) system, an electronic disclosure service provided by Financial Supervisory Service (FSS). After matching the respective data, the final sample size included 215 firms in 9 industries including pharmaceutical, chemical, and electronics. 


\section{Measures}

\section{Dependent Variable}

Firm risk is composed of systematic risk and unsystematic risk. While systematic risk is related to market risk and retains force to which all companies are susceptible, unsystematic risk indicates unique or asset-specific risk of a firm (Ross et al., 2008). Many scholars suggested an integrated view combining both the systematic risk and the unsystematic risk is appropriate to evaluate firm risk because not only the market risk but also the firm specific risk affects profitability (Aaker \& Jacobson, 1987; Amit \& Wernerfelt, 1990; Jo \& Na, 2012). Accordingly, this study employs firm risk as total risk which is calculated as the sum of systematic risk and unsystematic risk (Shin \& Stulz, 2000). Specifically, unsystematic risk is measured by volatility that is $\log$ transformed standard deviation of daily stock returns, and systematic risk is measured by beta coefficient from the linear least-squares calculation.

\section{Independent Variables}

For the ownership variables, we consider management ownership and foreign ownership. In Korea, large ownershareholders have the predominant role and they influence most of the firm management decisions (Jung \& Kwon, 2002). Considering the Korean ownership context, this study measures management ownership as the percentage of equity shares owned by large shareholders including affiliated parties. Foreign ownership is measured by the proportion of equity held by foreign investors in relation to the total equity of the firm.

For the board effectiveness variables, we include outside director ratio and board size. Outside director ratio represents the board independence. We measure outside director ratio as the proportion of the number of outside directors regarding the total number of the board members. Meanwhile, board size has attracted attentions as another factor influencing board effectiveness. We measure board size as the number of board members.

We measure corporate social responsibility using KEJI index from the CCEJ. The KEJI index is composed of 7 indicators for social performances: (1) soundness, (2) fairness, (3) contribution to society, (4) consumer protection, (5) environmental protection, (6) employee satisfaction, and (7) contribution to economy, where each indicator takes from 0 to $20,11,7,7,10,10$, and 10, respectively. We employ the total scores.

\section{Control Variables}

This study controls for several variables that may affect a firm's risk: firm size, return on assets (ROA), advertising investment, research and development (R\&D) investment, and debt ratio (McConnell \& Servaes, 1990; Morck et al., 1988). We use the number of employees as a proxy for firm size. ROA is measured by dividing net income by the total assets. Furthermore, intangible capital aspects of both advertising and R\&D investment are emphasized as a significant factor influencing profitability (Chauvin \& Hirschey, 1993; Hirschey, 1982). We measure the advertising investment as the natural logarithm of advertising expenditures. We also collected data on $R \& D$ investment measured as the natural logarithm of R\&D investment. Meanwhile, debt ratio represents the financial leverage of a firm. Debt ratio is measured as the total debt divided by total assets.

\section{Analytic Method}

This study uses an unbalanced panel dataset of 640 firm-by-year cases between 2005 and 2010 . The choice of analytic method between fixed effects (FE) and random effects (RE) estimators can be controversial because while the RE model assumes exogeneity of all the independent variables and the random individual effects, the FE model assumes endogeneity of all the independent and the individual effects (Baltagi et al., 2003). By applying Hausman's (1978) recommendation, we employ the FE model for the analysis.

$$
\text { RISK }=\alpha+\beta_{1} \text { Governance }+\beta_{2} C S R+\beta_{3}(\text { Governance }) \times(C S R)+\beta_{4} \text { Controls }+\varepsilon
$$

Where RISK $=$ the total risk combined with systematic risk and unsystematic risk, Governance $=$ management ownership, foreign ownership, outside director ratio, and board size, CSR = the total scores of KEJI index, and Controls = firm size, ROA, advertising investment, R\&D investment, and debt ratio. 


\section{RESULTS}

Table 1 provides descriptive statistics for the variables and correlations between variables. We examined the variance inflation factor (VIF) test as the post estimation check. We found that there are no serious multicollinearity problems with the data.

We applied a number of nested regression models to elucidate how corporate governance and CSR influence firm risk. Table 2 shows that each increased R-square value from Model 1 to Model 12 demonstrates the model improvements. Model 1 includes only control variables. Corporate governance variables are added into Models 2, 3, 4 , and 5 in sequence. Model 6 includes all governance structure variables for easy comparison. From the models, the decreasing impacts of the foreign ownership and board size on firm risk are respectively significant, while the management ownership and ratio of outside director have no significant effect on firm risk, partially supporting Hypothesis 1 (i.e., supporting only Hypothesis $1 \mathrm{~b}$ and Hypothesis 1d). Models 7 to 12 indicate that CSR definitely reduces firm risk, supporting Hypothesis 2.

In the Models 8, 9, 10, and 11, each interaction term between CSR and governance structure variables is added to examine the moderating role of CSR. The results show that the moderating hypotheses are partially supported: that is, the moderating effect of CSR is only significant in both the relationship between management ownership and firm risk (Hypothesis 3a) and the relationship between board size and firm risk (Hypothesis 3d). It is notable that the interaction of management ownership with CSR has a significant and negative effect on firm risk, although the management ownership has no significant explanatory power by itself.

Table 1. Descriptive Statistics and Correlation Matrix

\begin{tabular}{|c|c|c|c|c|c|c|c|c|c|c|}
\hline No. & Variables & Mean & Std. Dev. & Min & Max & 1 & 2 & 3 & 4 & 5 \\
\hline 1 & RISK & 1.1904 & .4465 & .1273 & 2.5745 & & & & & \\
\hline 2 & CSR & 47.848 & 2.6277 & 43.1 & 58.11 & -.0320 & & & & \\
\hline 3 & MGT & 37.826 & 14.888 & 2.27 & 87.31 & $-.0992 *$ & $-.3199 *$ & & & \\
\hline 4 & FOR & 17.490 & 16.246 & 0 & 79.240 & $-.1267 *$ & $.3703 *$ & $-.2283 *$ & & \\
\hline 5 & OUT & .3785 & .1436 & 0 & 1 & $.1311^{*}$ & $.3858 *$ & $-.2743 *$ & $.2960 *$ & \\
\hline 6 & BRD & 6.6128 & 2.7004 & 0 & 19 & .0755 & $.2671^{*}$ & $-.1922 *$ & $.2947 *$ & $.3673^{*}$ \\
\hline 7 & ROA & 6.2663 & 5.3034 & -22.38 & 29.09 & $-.1163^{*}$ & $.2999 *$ & -.0772 & $.3283^{*}$ & $.1925^{*}$ \\
\hline 8 & SIZE & 3014.7 & 9116.3 & 16 & 85813 & $.1036^{*}$ & $.3127 *$ & $-.2750 *$ & $.3445^{*}$ & $.3075^{*}$ \\
\hline 9 & $\mathrm{ADV}$ & 14.637 & 2.7104 & 5.6733 & 21.878 & .0506 & $.4629 *$ & $-.2653 *$ & $.4286^{*}$ & $.3667^{*}$ \\
\hline 10 & RND & 14.557 & 2.4773 & 5.4638 & 22.723 & $.1740 *$ & $.4064 *$ & $-.2494 *$ & $.3480 *$ & $.2778^{*}$ \\
\hline 11 & LEV & 78.599 & 66.394 & 1.71 & 671.5 & $.3983 *$ & $-.0811 *$ & $-.1319 *$ & -.0712 & $.1086^{*}$ \\
\hline \multicolumn{11}{|c|}{ (Table 1 continued) } \\
\hline No. & Variables & Mean & Std. Dev. & Min & Max & 6 & 7 & 8 & 9 & 10 \\
\hline 1 & RISK & 1.1904 & .4465 & .1273 & 2.5745 & & & & & \\
\hline 2 & CSR & 47.848 & 2.6277 & 43.1 & 58.11 & & & & & \\
\hline 3 & MGT & 37.826 & 14.888 & 2.27 & 87.31 & & & & & \\
\hline 4 & FOR & 17.490 & 16.246 & 0 & 79.240 & & & & & \\
\hline 5 & OUT & .3785 & .1436 & 0 & 1 & & & & & \\
\hline 6 & BRD & 6.6128 & 2.7004 & 0 & 19 & & & & & \\
\hline 7 & ROA & 6.2663 & 5.3034 & -22.38 & 29.09 & $.1096^{*}$ & & & & \\
\hline 8 & SIZE & 3014.7 & 9116.3 & 16 & 85813 & $.3321 *$ & $.1433 *$ & & & \\
\hline 9 & $\mathrm{ADV}$ & 14.637 & 2.7104 & 5.6733 & 21.878 & $.3925 *$ & $.2367 *$ & $.4514 *$ & & \\
\hline 10 & RND & 14.557 & 2.4773 & 5.4638 & 22.723 & $.3565^{*}$ & $.1295^{*}$ & $.4954 *$ & $.5562 *$ & \\
\hline 11 & LEV & 78.599 & 66.394 & 1.71 & 671.5 & $.1917 *$ & $-.2884 *$ & .0764 & $.1264 *$ & $.1638^{*}$ \\
\hline
\end{tabular}

No. Obs. $=640$, significant level: $* \mathrm{p}<.05$.

RISK: Total risk, CSR: Corporate social responsibility, MGT: Management ownership, FOR: Foreign ownership, OUT: Outside director ratio, BRD: Number of board members (proxy for board size), ROA: Return on assets, SIZE: Number of employees (proxy for firm size), ADV: Natural logarithm of advertising expenditures, RND: Natural logarithm of research and development investment, LEV: Debt ratio (proxy for firm's leverage).

However, although foreign ownership has a strong negative effect on firm risk, we didn't find any interaction effect of foreign ownership and CSR in Models 9 and 12. In addition, the moderating effect of CSR on the relationship between outside director ratio and firm risk seems to be non-significant. Subsequently, the full model (i.e., Model 
12) including all interaction terms reconfirms that each interaction of the corporate governance variables and CSR generates different impacts on firm risk. Consequently, these empirical results provide evidence for our main argument that CSR as moral assets, the broad view of the firm's role and effort to take care stakeholders, should be considered to explain a firm's social responsibility activities and its subsequent performance.

Table 2. Fixed-effects Regression Estimation (Dep. Variable: Firm Risk)

\begin{tabular}{|c|c|c|c|c|c|c|}
\hline & Model 1 & Model 2 & Model 3 & Model 4 & Model 5 & Model 6 \\
\hline Constant & $\begin{array}{r}.9359 \dagger \\
(.4863)\end{array}$ & $\begin{array}{r}.9169 \dagger \\
(.5172)\end{array}$ & $\begin{array}{l}1.0298^{*} \\
(.4833)\end{array}$ & $\begin{array}{c}.9696^{*} \\
(.4868)\end{array}$ & $\begin{array}{l}1.1206^{*} \\
(.4919)\end{array}$ & $\begin{array}{l}1.2357^{*} \\
(.5200)\end{array}$ \\
\hline $\mathrm{ROA}$ & $\begin{array}{l}-.0033 \\
(.0039)\end{array}$ & $\begin{array}{l}-.0033 \\
(.0039)\end{array}$ & $\begin{array}{l}-.0020 \\
(.0039)\end{array}$ & $\begin{array}{l}-.0032 \\
(.0039) \\
\end{array}$ & $\begin{array}{l}-.0029 \\
(.0039) \\
\end{array}$ & $\begin{array}{l}-.0018 \\
(.0039) \\
\end{array}$ \\
\hline SIZE & $\begin{array}{l}.0001^{*} \\
(.00003)\end{array}$ & $\begin{array}{l}-.0001^{*} \\
(.00003)\end{array}$ & $\begin{array}{l}-.0001 \dagger \\
(.00003)\end{array}$ & $\begin{array}{l}-.0001 * \\
(.00003)\end{array}$ & $\begin{array}{l}-.0001 \dagger \\
(.00003)\end{array}$ & $\begin{array}{l}.0001 \\
(.00003)\end{array}$ \\
\hline ADV & $\begin{array}{c}.0610^{*} \\
(.0267)\end{array}$ & $\begin{array}{c}.0609 * \\
(.0268)\end{array}$ & $\begin{array}{c}.0656^{*} \\
(.0266)\end{array}$ & $\begin{array}{c}.0620^{*} \\
(.0267)\end{array}$ & $\begin{array}{c}.0646^{*} \\
(.0267)\end{array}$ & $\begin{array}{l}.0693^{* *} \\
(.0266)\end{array}$ \\
\hline RND & $\begin{array}{l}-.0418^{*} \\
(.0211) \\
\end{array}$ & $\begin{array}{l}-.0417^{*} \\
(.0211)\end{array}$ & $\begin{array}{l}-.0446^{*} \\
(.0209) \\
\end{array}$ & $\begin{array}{l}-.0402 \dagger \\
(.0211) \\
\end{array}$ & $\begin{array}{l}-.0497^{*} \\
(.0213)\end{array}$ & $\begin{array}{l}-.0502^{*} \\
(.0213)\end{array}$ \\
\hline LEV & $\begin{array}{l}.0022^{* * * *} \\
(.0005)\end{array}$ & $\begin{array}{l}.0022 * * * \\
(.0005)\end{array}$ & $\begin{array}{l}.0019 * * * \\
(.0005)\end{array}$ & $\begin{array}{l}.0022 * * * \\
(.0005)\end{array}$ & $\begin{array}{l}.0022 * * * \\
(.0005)\end{array}$ & $\begin{array}{l}.0019 * * * \\
(.0005)\end{array}$ \\
\hline MGT & & $\begin{array}{c}.0004 \\
(.0040)\end{array}$ & & & & $\begin{array}{l}-.0006 \\
(.0039)\end{array}$ \\
\hline FOR & & & $\begin{array}{l}-.0074 * * \\
(.0026)\end{array}$ & & & $\begin{array}{l}-.0069^{* *} \\
(.0027)\end{array}$ \\
\hline OUT & & & & $\begin{array}{l}-.2213 \\
(.1829)\end{array}$ & & $\begin{array}{l}.1695 \\
(.1819)\end{array}$ \\
\hline BRD & & & & & $\begin{array}{l}-.0221^{*} \\
(.0104)\end{array}$ & $\begin{array}{l}-.0193 \dagger \\
(.0104)\end{array}$ \\
\hline \multicolumn{7}{|l|}{ CSR } \\
\hline \multicolumn{7}{|l|}{$\mathrm{MGT} \times \mathrm{CSR}$} \\
\hline \multicolumn{7}{|l|}{$\mathrm{FOR} \times \mathrm{CSR}$} \\
\hline \multicolumn{7}{|l|}{ OUT $\times$ CSR } \\
\hline \multicolumn{7}{|l|}{$\mathrm{BRD} \times \mathrm{CSR}$} \\
\hline R-square & .0729 & .0729 & .0905 & .0761 & .0828 & .1002 \\
\hline F-value & $6.60 * * *$ & $5.49 * * *$ & $6.94 * * *$ & $5.75 * * *$ & $6.31 * * *$ & $5.15^{* * *}$ \\
\hline No. of Obs. & 640 & 640 & 640 & 640 & 640 & 640 \\
\hline
\end{tabular}


(Table 2 Continued)

\begin{tabular}{|c|c|c|c|c|c|c|}
\hline & Model 7 & Model 8 & Model 9 & Model 10 & Model 11 & Model 12 \\
\hline Constant & $\begin{array}{l}1.9225 * * \\
(.6288)\end{array}$ & $\begin{array}{l}2.0426^{* * *} \\
(.6307)\end{array}$ & $\begin{array}{l}1.9459 * * \\
(.6307)\end{array}$ & $\begin{array}{l}1.9269 * * \\
(.6299)\end{array}$ & $\begin{array}{l}1.8956^{* *} \\
(.6276)\end{array}$ & $\begin{array}{l}2.1014 * * * \\
(.6320)\end{array}$ \\
\hline ROA & $\begin{array}{l}.0015 \\
(.0039)\end{array}$ & $\begin{array}{l}-.0012 \\
(.0039)\end{array}$ & $\begin{array}{l}.0014 \\
(.0039)\end{array}$ & $\begin{array}{l}.0015 \\
(.0039)\end{array}$ & $\begin{array}{l}-.0016 \\
(.0039)\end{array}$ & $\begin{array}{l}-.0013 \\
(.0039)\end{array}$ \\
\hline SIZE & $\begin{array}{l}-.0001 \dagger \\
(.00003)\end{array}$ & $\begin{array}{l}-.00004 \\
(.00003)\end{array}$ & $\begin{array}{l}-.0001 \dagger \\
(.00003)\end{array}$ & $\begin{array}{l}-.0001 \dagger \\
(.00003)\end{array}$ & $\begin{array}{l}-.0001 \dagger \\
(.00003)\end{array}$ & $\begin{array}{l}-.0001 \dagger \\
(.00003)\end{array}$ \\
\hline $\mathrm{ADV}$ & $\begin{array}{l}.0719 * * \\
(.0265)\end{array}$ & $\begin{array}{l}.0738 * * \\
(.0265)\end{array}$ & $\begin{array}{l}.0707 * * \\
(.0266)\end{array}$ & $\begin{array}{l}.0721 * * \\
(.0266)\end{array}$ & $\begin{array}{l}.0722 * * \\
(.0265)\end{array}$ & $\begin{array}{l}.0741 * * \\
(.0265)\end{array}$ \\
\hline RND & $\begin{array}{l}-.0460 * \\
(.0213)\end{array}$ & $\begin{array}{l}-.0475^{*} \\
(.0213)\end{array}$ & $\begin{array}{l}-.0449 * \\
(.0214)\end{array}$ & $\begin{array}{l}-.0457 * \\
(.0214)\end{array}$ & $\begin{array}{l}-.0469 * \\
(.0213)\end{array}$ & $\begin{array}{l}-.0470 * \\
(.0214)\end{array}$ \\
\hline LEV & $\begin{array}{l}.0019 * * * \\
(.0005)\end{array}$ & $\begin{array}{l}.0020 * * * \\
(.0005)\end{array}$ & $\begin{array}{l}.0020 * * * \\
(.0005)\end{array}$ & $\begin{array}{l}.0019 * * * \\
(.0005)\end{array}$ & $\begin{array}{l}.0019 * * * \\
(.0005)\end{array}$ & $\begin{array}{l}.0020 * * * \\
(.0005)\end{array}$ \\
\hline MGT & $\begin{array}{l}.0009 \\
(.0039)\end{array}$ & $\begin{array}{l}.0005 \\
(.0039)\end{array}$ & $\begin{array}{l}.0011 \\
(.0040)\end{array}$ & $\begin{array}{l}.0009 \\
(.0039)\end{array}$ & $\begin{array}{l}.0018 \\
(.0040)\end{array}$ & $\begin{array}{l}.0018 \\
(.0040)\end{array}$ \\
\hline FOR & $\begin{array}{l}-.0066^{*} \\
(.0026)\end{array}$ & $\begin{array}{l}-.0070 * * \\
(.0027)\end{array}$ & $\begin{array}{l}-.0063 * \\
(.0027)\end{array}$ & $\begin{array}{l}-.0066^{*} \\
(.0027)\end{array}$ & $\begin{array}{l}-.0068 * * \\
(.0026)\end{array}$ & $\begin{array}{l}-.0072 * * \\
(.0027)\end{array}$ \\
\hline OUT & $\begin{array}{l}-.1648 \\
(.1813)\end{array}$ & $\begin{array}{l}-.1652 \\
(.1808)\end{array}$ & $\begin{array}{l}-.1647 \\
(.1814)\end{array}$ & $\begin{array}{l}-.1655 \\
(.1815)\end{array}$ & $\begin{array}{l}-.1445 \\
(.1813)\end{array}$ & $\begin{array}{l}-.1395 \\
(.1806)\end{array}$ \\
\hline BRD & $\begin{array}{l}-.0197 \dagger \\
(.0103)\end{array}$ & $\begin{array}{l}-.0222^{*} \\
(.0104)\end{array}$ & $\begin{array}{l}-.0190 \dagger \\
(.0104)\end{array}$ & $\begin{array}{l}-.0199 \dagger \\
(.0105)\end{array}$ & $\begin{array}{c}-.0188 \dagger \\
(.0103)\end{array}$ & $\begin{array}{l}-.0220 * \\
(.0105)\end{array}$ \\
\hline CSR & $\begin{array}{l}-.0161 \dagger \\
(.0084)\end{array}$ & $\begin{array}{l}-.0192 * \\
(.0085)\end{array}$ & $\begin{array}{l}-.0163 \dagger \\
(.0084)\end{array}$ & $\begin{array}{l}-.0164 \dagger \\
(.0085)\end{array}$ & $\begin{array}{c}-.0143 \dagger \\
(.0084)\end{array}$ & $\begin{array}{c}-.0191 * \\
(.0086)\end{array}$ \\
\hline $\mathrm{MGT} \times \mathrm{CSR}$ & & $\begin{array}{l}-.0365 \dagger \\
(.0204)\end{array}$ & & & & $\begin{array}{l}-.0515^{*} \\
(.0216)\end{array}$ \\
\hline FOR $\times$ CSR & & & $\begin{array}{l}-.0129 \\
(.0230)\end{array}$ & & & $\begin{array}{l}-.0179 \\
(.0246)\end{array}$ \\
\hline $\mathrm{OUT} \times \mathrm{CSR}$ & & & & $\begin{array}{c}.0035 \\
(.0172)\end{array}$ & & $\begin{array}{c}.0120 \\
(.0182)\end{array}$ \\
\hline $\mathrm{BRD} \times \mathrm{CSR}$ & & & & & $\begin{array}{c}.0304 \dagger \\
(.0181)\end{array}$ & $\begin{array}{l}-.0426^{*} \\
(.0195)\end{array}$ \\
\hline R-square & .1082 & .1151 & .1089 & .1083 & .1143 & .1276 \\
\hline F-value & $5.04 * * *$ & $4.89 * * *$ & $4.60 * * *$ & $4.57 * * *$ & $4.86^{* * *}$ & $4.29 * * *$ \\
\hline No. of Obs. & 640 & 640 & 640 & 640 & 640 & 640 \\
\hline
\end{tabular}

Significant level: $* \mathrm{p}<.05 ; * * \mathrm{p}<.01 ; * * * \mathrm{p}<.001 ; \dagger \mathrm{p}<.1$, Numbers in parenthesis are standard error.

RISK: Total risk, CSR: Corporate social responsibility, MGT: Management ownership, FOR: Foreign ownership, OUT: Outside director ratio, BRD: Number of board members (proxy for board size), ROA: Return on assets, SIZE: Number of employees (proxy for firm size), ADV: Natural logarithm of advertising expenditures, RND: Natural logarithm of research and development investment, LEV: Debt ratio (proxy for firm's leverage).

\section{DISCUSSION AND IMPLICATIONS}

This study began with the argument that if firms are engaged in CSR, they can yield moral assets from good relations with stakeholders. Intangible assets from CSR can influence members' incentives and decision-making procedures in corporate governance, strengthening the link between CSR and corporate governance. Accordingly, we posited that CSR has a decreasing impact on the relationship between corporate governance and firm risk. The empirical findings tested our hypotheses.

First, the results of this study did not support for the relationship between management ownership and firm risk, implying that the power of senior managers in the concentrated ownership structure of (at least) Korean large publicly-owned firms is not significantly influencing firm risk. However, the results illustrate that the role of the foreign shareholders is considerable in the Korean context: that is, it seems that foreign shareholders are likely to mitigate agency problems in corporate governance by playing the role as monitors. However, the results did not support the relationship between outside director ratio and firm risk. It is plausible that the significance of board 
independence ensured from the large proportion of outside directors is obscure. In addition, it seems that the large size for the board of directors, as this study predicted, may contribute to the effective operation of the governance mechanisms.

This study also identified that CSR has a decreasing impact on firm risk since it creates moral assets. This social capital enables firms to have better access to diverse external information as well as more committed stakeholders. The moderating effect of CSR on the relationship between governance structure and firm risk, the primary concern of this study, was partially supported. Specifically, although management ownership by itself does not have a significant effect on firm risk, the interaction term between CSR and management ownership has a significant effect on firm risk. This result implies that CSR can generate social connections to monitor manager's behaviors, and thereby it enhances transparency and influences stability of the firm. CSR also strengthens the impact of the board size on the firm risk. It seems that moral benefits of CSR enable the board of directors to function more appropriately in accordance with greater legitimacy.

On the other hand, CSR was not significant in moderating the relationship between foreign ownership and firm risk and the relationship between outside director ratio and firm risk. We predicted that CSR engagement would be a motivation for foreign shareholders to dedicate to their functions because CSR represents a long-term performance orientation and foreign shareholders generally have long-term interests. However, we found that the significant relationship between foreign ownership and firm risk disappeared in the moderating models. These results imply that the signals of social performance may let foreign shareholders being slack in their functions. CSR may not have a moderating effect on the board effectiveness through an improved independent monitoring role of outside directors.

The findings of this study have theoretical and practical implications. Regarding theoretical implications, first, this study provides an integrated model linking corporate governance and CSR. By incorporating CSR into the corporate governance model, we can observe how firms' socially responsible roles and functions influence the governanceperformance mechanism. Second, this study identifies the importance of stakeholder perspective. Although the existing empirical studies were unconcerned with how the concept of the stakeholder can be combined with other strategic management issues such as governance structure, this study demonstrates that corporate governance should be precisely interpreted with the consideration of corporate social responsibilities. This study has managerial implications. First, firms need to arrange the operations of corporate governance mechanisms by reflecting the impact of CSR in managing firm risk. Second, given that CSR has different degrees of moderating effects on the relationships between governance structure variables and firm risk, managers in Korean large publicly-owned firms need to only pay heed to a few related governance structure factors rather than all of them.

This study has several limitations that need to be addressed in future research. First, this study tests our main concern in the Korean business context, which is characterized by the concentrated ownership structures. Accordingly, the findings can be generalized by applying the characteristics other countries' business environments. Second, this study suggests a conceptual framework to explain a link of corporate governance, CSR, and firm risk, but we admit that the evidence for the causality of whether the social asset does actually matter in the model is needed to be further explored, given our results partially support the hypotheses in question. Lastly, we restrict our sample only to KEJI top 200 firms because only KEJI index is open to the public. The future research is necessary to extend the sample size.

\section{CONCLUSION}

This study departs from the existing studies as follows. First, this study expands the scope of research by providing an integrated model of corporate governance and CSR. Second, this study contributes to firms' risk management by identifying that firm risk also can be reduced by including corporate social responsibility activities into the main strategy area. Lastly, this study suggests that further research be comprehensive to link the stakeholder perspective and the governance structure model to evaluate firms' social responsible roles and their subsequent effect on firm risk. 


\section{AUTHOR BIOGRAPHIES}

Sewon Lee received her Master degree at School of Business, Ajou University. Her research areas include corporate strategy, corporate social responsibility, and corporate governance and firm performance.

Young Kon Kim, Ph.D., is an associate professor at School of Business, Ajou University. He received his PhD in Management from University of California at Los Angeles. His research areas include corporate strategy and international business strategy.

Kyungho Kim, DBA, is an assistant professor at School of Business, Ajou University. He received his DBA from Boston University. His research areas include corporate strategy, international business strategy, corporate social responsibility, and environmental sustainability. Please direct all correspondence to Kyungho Kim (kyunghokim@ajou.ac.kr).

\section{REFERENCES}

Aaker, D. A., \& Jacobson, R. (1987). The role of risk in explaining differences in profitability. Academy of Management Journal, 30(2), 277-296.

Adams, R. B., Almeida, H., \& Ferreira, D. (2005). Powerful CEOs and their impact on corporate performance. Review of Financial Studies, 18(4), 1403-1432.

Agrawal, A. \& Mandelker, G. N. (1987). Managerial incentives and corporate investment and financing decision. The Journal of Finance, 42(4), 823-837.

Amit, R., \& Wernerfelt, B. (1990). Why do firms reduce business risk? Academy of Management Journal, 33(3), $520-533$.

Aupperle, K. E., Carroll, A. B., \& Hatfield, J. D. (1985). An empirical examination of the relationship between corporate social responsibility and profitability. Academy of Management Journal, 28(2), 446-463.

Baek, J. S., Kang, J. K., \& Park, K. S. (2004). Corporate governance and firm value: Evidence from the Korean financial crisis. Journal of Financial economics, 71(2), 265-313.

Baird, I. S., \& Thomas, H. (1985). Toward a contingency model of strategic risk taking. Academy of Management Review, 10(2), 230-243.

Baltagi, B. H., Bresson, G., \& Pirotte, A. (2003). Fixed effects, random effects or Hausman-Taylor? A pretest estimator. Economics Letters, 79(3), 361-369.

Baysinger, B. D., \& Butler, H. N. (1985). Corporate governance and the board of directors: Performance effects of changes in board composition. Journal of Law, Economics, \& Organization, 1(1), 101-124.

Bénabou, R., \& Tirole, J. (2010). Individual and corporate social responsibility. Economica, 77(305), 1-19.

Berle, A. A., \& Means, G. G. C. (1932). The modern corporation and private property. New York: Macmillan.

Bloom, M., \& Milkovich, G. T. (1998). Relationships among risk, incentive pay, and organizational performance. Academy of Management Journal, 41(3), 283-297.

Bowman, E. H. (1980). A risk/return paradox for strategic management. Sloan Management Review, 21(3): 17-31.

Byrd, J. W., \& Hickman, K. A. (1992). Do outside directors monitor managers? Evidence from tender offer bids. Journal of Financial Economics, 32(2), 195-221.

Chauvin, K. W., \& Hirschey, M. (1993). Advertising, R\&D expenditures and the market value of the firm. Financial Management, 22(4), 128-140.

Cheng, B., Ioannou, I., \& Serafeim, G. (2014). Corporate social responsibility and access to finance. Strategic Management Journal, 35(1), 1-23.

Cheng, S. (2008). Board size and the variability of corporate performance. Journal of Financial Economics, 87(1), $157-176$.

Cho, D. S., \& Kim, J. (2007). Outside directors, ownership structure and firm profitability in Korea. Corporate Governance: An International Review, 15(2), 239-250.

Choi, J. J., Park, S. W., \& Yoo, S. S. (2007). The value of outside directors: Evidence from corporate governance reform in Korea. Journal of Financial and Quantitative Analysis, 42(4), 941-962.

Choi, J., \& Wang, H. (2009). Stakeholder relations and the persistence of corporate financial performance. Strategic Management Journal, 30(8), 895-907.

Claessens, S., Djankov, S., \& Lang, L. H. (2000). The separation of ownership and control in East Asian corporations. Journal of Financial Economics, 58(1), 81-112.

Clarkson, M. E. (1995). A stakeholder framework for analyzing and evaluating corporate social performance. Academy of Management Review, 20(1), 92-117.

Cochran, P. L., \& Wood, R. A. (1984). Corporate social responsibility and financial performance. Academy of Management Journal, 27(1), 42-56.

Cornell, B., \& Shapiro, A. C. (1987). Corporate stakeholders and corporate finance. Financial Management, 16(1), 5-14. 
Dalton, D. R., Daily, C. M., Ellstrand, A. E., \& Johnson, J. L. (1998). Meta-analytic reviews of board composition, leadership structure, and financial performance. Strategic Management Journal, 19(3), 269-290.

Dalton, D. R., Daily, C. M., Johnson, J. L., \& Ellstrand, A. E. (1999). Number of directors and financial performance: A metaanalysis. Academy of Management Journal, 42(6), 674-686.

Eccles, R. G., Ioannou, I., \& Serafeim, G. (2014). The impact of corporate sustainability on organizational processes and performance. Management Science, 60(11), 2835-2857.

Fama, E. F., \& Jensen, M. C. (1983). Separation of ownership and control. Journal of Law and Economics, 26(2), 301-325.

Fiegenbaum, A., \& Thomas, H. (1988). Attitudes toward risk and the risk-return paradox: Prospect theory explanations. Academy of Management Journal, 31(1), 85-106.

Freeman, R. E. (1984). Strategic management: A stakeholder approach. Pitman: Boston, MA.

Freeman, R. E., \& Reed, D. L. (1983). Stockholders and stakeholders: A new perspective in corporate governance. California Management Review, 25(3), 88-106.

Freeman, R. E., Wicks, A. C., \& Parmar, B. (2004). Stakeholder theory and "the corporate objective revisited". Organization Science, 15(3), 364-369.

Godfrey, P. C. (2005). The relationship between corporate philanthropy and shareholder wealth: A risk management perspective. Academy of Management Review, 30(4), 777-798.

Godfrey, P. C., Merrill, C. B., \& Hansen, J. M. (2009). The relationship between corporate social responsibility and shareholder value: An empirical test of the risk management hypothesis. Strategic Management Journal, 30(4), 425-445.

Hausman, J. A. (1978). Specification tests in econometrics. Econometrica, 46(6), 1251-1271.

Herremans, I. M., Akathaporn, P., \& McInnes, M. (1993). An investigation of corporate social responsibility reputation and economic performance. Accounting, Organizations and Society, 18(7), 587-604.

Hillman, A. J., \& Keim, G. D. (2001). Shareholder value, stakeholder management, and social issues: What's the bottom line? Strategic Management Journal, 22(2), 125-139.

Hirschey, M. (1982). Intangible capital aspects of advertising and R \& D expenditures. The Journal of Industrial Economics, 30(4), 375-390.

Jensen, M. C., \& Meckling, W. H. (1976). Theory of the firm: Managerial behavior, agency costs, and ownership structure. Journal of Financial Economics, 3(4), 305-360.

Jo, H., \& Na, H. (2012). Does CSR reduce firm risk? Evidence from controversial industry sectors. Journal of Business Ethics, $110(4), 441-456$.

Joh, S. W. (2003). Corporate governance and firm profitability: Evidence from Korea before the economic crisis. Journal of financial Economics, 68(2), 287-322.

Jones, T. M. (1995). Instrumental stakeholder theory: A synthesis of ethics and economics. Academy of Management Review, 20(2), 404-437.

Jung, K., \& Kwon, S. Y. (2002). Ownership structure and earnings informativeness: Evidence from Korea. The International Journal of Accounting, 37(3), 301-325.

Kang, J. (2013). The relationship between corporate diversification and corporate social performance. Strategic Management Journal, 34(1), 94-109.

Lee, S. C., Kim, J., \& Park, A. Y. (2005). Agency problems and firm value: Evidence from Korea. Korean Journal of Management Accounting Research, 5(1), 33-55.

Luoma, P., \& Goodstein, J. (1999). Stakeholders and corporate boards: Institutional influences on board composition and structure. Academy of Management Journal, 42(5), 553-563.

Margolis, J. D., Elfenbein, H. A., \& Walsh, J. P. (2007). Does it pay to be good? A meta-analysis and redirection of research on the relationship between corporate social and financial performance. (Working Paper), Harvard Business School, Boston, MA.

McConnell, J. J., \& Servaes, H. (1990). Additional evidence on equity ownership and corporate value. Journal of Financial Economics, 27(2), 595-612.

McWilliams, A., \& Siegel, D. (2000). Research notes and communications. Corporate social responsibility and financial performance: Correlation or misspecification? Strategic Management Journal, 21(5), 603-609.

Morck, R., Shleifer, A., \& Vishny, R. W. (1988). Management ownership and market valuation: An empirical analysis. Journal of Financial Economics, 20, 293-315.

Oh, W. Y., Chang, Y. K., \& Martynov, A. (2011). The effect of ownership structure on corporate social responsibility: Empirical evidence from Korea. Journal of business ethics, 104(2), 283-297.

Orlitzky, M., \& Benjamin, J. D. (2001). Corporate social performance and firm risk: A meta-analytic review. Business \& Society, 40(4), 369-396.

Park, H. J., Shin, H. H., \& Choi, W. S. (2004). The Korean firms' agency costs and firm value: Role of foreign investors' equity ownership. Korean Management Review, 33(2), 655-682.

Park, J. H., \& Noh, E. J. (2008). Effects of a firm's ownership structure on agency costs: Focusing on the effects of foreign ownership and top management ownership. Korean Journal of Management Accounting Research, 8(1), 143-164.

Preston, L. E., \& O’Bannon, D. P. (1997). The corporate social-financial performance relationship: A typology and analysis. Business and Society, 36(4), 419-429. 
Roberts, P. W., \& Dowling, G. R. (2002). Corporate reputation and sustained superior financial performance. Strategic Management Journal, 23(12), 1077-1093.

Ross, S. A., Westerfield, R., \& Jordan, B. D. (2008). Fundamentals of corporate finance. McGraw-Hill Education.

Shin, H. H., \& Stulz, R. M. (2000). Firm value, risk, and growth opportunities. (Working paper No. 7808). National Bureau of Economic Research.

Shleifer, A., \& Vishny, R. W. (1986). Large shareholders and corporate control. The Journal of Political Economy, 94(3), 461488.

Surroca, J., Tribó, J. A., \& Waddock, S. (2010). Corporate responsibility and financial performance: The role of intangible resources. Strategic Management Journal, 31(5), 463-490.

Ullmann, A. A. (1985). Data in search of a theory: A critical examination of the relationships among social performance, social disclosure, and economic performance of US firms. Academy of Management Review, 10(3), 540-557.

Waddock, S. A., \& Graves, S. B. (1997). The corporate social performance-financial performance link. Strategic Management Journal, 18(4), 303-319. 


\section{NOTES}

